\title{
New Thermal and Microbial Resistant Metal-Containing Epoxy Polymers
}

\author{
Tansir Ahamad and Saad M. Alshehri \\ Department of Chemistry, King Saud University, Riyadh11451, Saudi Arabia \\ Correspondence should be addressed to Saad M. Alshehri, alshehri@ksu.edu.sa \\ Received 7 December 2009; Revised 24 February 2010; Accepted 10 April 2010 \\ Academic Editor: Spyros Perlepes
}

Copyright (C) 2010 T. Ahamad and S. M. Alshehri. This is an open access article distributed under the Creative Commons Attribution License, which permits unrestricted use, distribution, and reproduction in any medium, provided the original work is properly cited.

\begin{abstract}
A series of metal-containing epoxy polymers have been synthesized by the condensation of epichlorohydrin (1-chloro-2,3-epoxy propane) with Schiff base metal complexes in alkaline medium. Schiff base was initially prepared by the reaction of 2,6 dihydroxy 1-napthaldehyde and $o$-phenylenediamine in $1: 2$ molar ratio and then with metal acetate. All the synthesized compounds were characterized by elemental, spectral, and thermal analysis. The physicochemical properties, viz., epoxy value, hydroxyl content, and chlorine content $[\mathrm{mol} / 100 \mathrm{~g}]$ were measured by standard procedures. The antimicrobial activities of these metal-containing epoxy polymers were carried out by using minimum inhibitory concentration (MIC) and minimum bactericidal concentration (MBC) methods against S. aureus, B. subtilis (Gram-positive bacteria), and E. coli, P. aeruginosa (Gram-negative bacteria). It was found that the $\mathrm{ECu}(\mathrm{II})$ showed higher antibacterial activity than other metal-chelated epoxy resin while EMn(II) exhibited reduced antibacterial activity against all bacteria.
\end{abstract}

\section{Introduction}

Since the last two decades, several thermal and microbial resistant polymers have been synthesized by the immobilization of metal complexes into the polymers [1] and used as a thermal resistant, microbial resistant, scratch resistant, and flame retardant-coating materials. Some metal complexes commonly used in the synthesis of metal containing polymers are Schiff base, ferrocene, Imidazole, secondary and tresiory amine metal complexes, and so forth, $[2,3]$. Among these metal complexes Schiff base metal complexes have been widely used due to their corrosive resistant, microbial as well as thermal resistant properties [4]. Epoxy polymers are one of the most important higher-performance polymer systems in use today, ranging from simple two-part adhesives and sports equipment to high-tech applications such as formula one racing cars and the aerospace industry. Epoxy polymers are capable of undergoing homopolymerisation, although this process generally yields products with inadequate properties for high-tech applications. Consequently, in many cases catalysts, additives, and cocuring-agents are formulated with the epoxy resin to significantly increase the storage stability, decrease the cure time, and improve the final properties $[5,6]$. The use of metals to formulate resin systems with excellent storage stability is discussed, along with the use of coordination compounds to improve cured resin properties such as fracture toughness, thermal stability, and water absorption $[7,8]$. Two approaches are generally used for the attachment of metal complexes with polymers. The first approach involves the introduction of the bifunctional metal complexes as a monomer, followed by their polymerization [9]. The second approach involves the linking of metal complexes directly onto preformed functional polymers [10]. The first approach has the advantage that the monomer can be polymerized with several other comonomers, and the composition can be varied easily. These facts propagated our interest at this time to synthesize new materials with antimicrobial and thermal resistance properties. In the present study, Schiff base metal complexes were reacted with epichlorohydrin in $1.25: 1$ molar ratios to produce a series of E-M(II) metal containing epoxy polymers. The characterization of the new epoxy polymers was done with 
the purpose of proposing their structures and determining their specific applications as thermally resistant and/or microbial resistant materials.

\section{Experimental}

2.1. Materials and Reagents. o-phenylenediamine, epichlorohydrin, manganese(II) acetate tetrahydrate $\left[\mathrm{Mn}\left(\mathrm{CH}_{3}\right.\right.$ $\left.\mathrm{COO})_{2}-4 \mathrm{H}_{2} \mathrm{O}\right]$, copper(II) acetate monohydrate $\left[\mathrm{Cu}\left(\mathrm{CH}_{3}\right.\right.$ $\left.\mathrm{COO})_{2}-\mathrm{H}_{2} \mathrm{O}\right]$, nickel(II) acetate tetrahydrate $\left[\mathrm{Ni}\left(\mathrm{CH}_{3}\right.\right.$ $\left.\mathrm{COO})_{2}-4 \mathrm{H}_{2} \mathrm{O}\right]$, cobalt(II) acetate tetrahydrate $\left[\mathrm{Co}\left(\mathrm{CH}_{3}\right.\right.$ $\left.\mathrm{COO})_{2}-4 \mathrm{H}_{2} \mathrm{O}\right]$, and $\mathrm{zinc}(\mathrm{II})$ acetate dihydrate $\left[\mathrm{Zn}\left(\mathrm{CH}_{3}\right.\right.$ $\mathrm{COO})_{2}-2 \mathrm{H}_{2} \mathrm{O}$ ] (Sigma Aldrich) were used without further purification. The solvents, such as dimethylformamide (DMF), dimethyl sulfoxide (DMSO), ethyl alcohol, methanol, and acetone, were distilled before use. 2,6-hydroxy naphthaldehyde was prepared according to the literature [11].

\subsection{Measurements}

Characterization for UV, FTIR, and NMR. The epoxy value $(\mathrm{mol} / 100 \mathrm{~g})$ of resin was determined by analytical method [12]. This method was based on the back titration. $0.2 \mathrm{~g}$ of resin was added to $30 \mathrm{~cm}^{3}$ of $0.1 \mathrm{M}-\mathrm{HCl}$ and mixed for $2 \mathrm{~h}$. Then unreacted $\mathrm{HCl}$ was retitrated with phenolphthalein by standard alkali solution using the following formula:

$$
\mathrm{w}(\mathrm{EP})=\frac{\left(V_{2}-V_{1}\right) \cdot c(\mathrm{NaOH}) \times 0.043}{\text { mass of sample }},
$$

where $V_{1}$ is the volume of $\mathrm{NaOH}$ solution used for blank and $V_{2}$ is the volume of $\mathrm{NaOH}$ solution used for sample.

Hydroxyl content was determined by acetylation with acetyl chloride in pyridine. The excess of acetyl chloride was decomposed with water and the resulting acetic acid, formed both in hydrolysis and in the acetylation process, was titrated with standard alkali using the following formula:

$$
\mathrm{w}(\mathrm{OH})=\frac{\text { mass of sample }}{\left(V_{1}-V_{2}\right) \cdot c(\mathrm{KOH}) \times 170},
$$

where $V_{1}$ is the volume of $\mathrm{KOH}$ solution used for blank and $V_{2}$ is the volume of $\mathrm{KOH}$ solution used for sample. The chlorine content was determined by treating the resin solution with alcoholic $\mathrm{KOH}$ and titrating it against standard $\mathrm{HCl}[13]$

$$
(\mathrm{Cl})=\frac{\mathrm{c}(\mathrm{KOH}) \cdot V \times 0.0355}{\text { mass of sample }} .
$$

2.3. Synthesis of Schiff Base Ligand $\left(\mathrm{H}_{2} \mathrm{~L}\right)$. Schiff base ligand was prepared by $(1.88 \mathrm{~g}, 0.01 \mathrm{~mol})$ of monoaldehyde and was dissolved in $8 \mathrm{~mL}$ of THF, and the solution was added to a $\mathrm{THF} / \mathrm{MeOH}(1 ; 110 \mathrm{~mL})$ solution of o-phenylenediamine $(0.9 \mathrm{~g}, 0.005 \mathrm{~mol})$ and refluxed for 6 hours. With continuous stirring the color of the solution has been changed reddish. The progress of reaction was monitored by thin layer chromatography (TLC). The reaction mixture was cooled and precipitated into $20 \mathrm{~mL} \mathrm{MeOH}$. The reddish purple colour precipitate was filtered, then washed with methanol, and dried in vacuum, Yield 45\% (2.01 g).
2.4. Synthesis of Schiff Base Metal Complexes. A solution of $2.13 \mathrm{~g}(0.1 \mathrm{~mol})$ of $\mathrm{H}_{2} \mathrm{~L}$ and 0.05 mol of metal acetate hydrates in $25 \mathrm{~cm}^{3}$ of ethanol were stirred for $2 \mathrm{~h}$ at $70^{\circ} \mathrm{C}$. Then, the mixture was cooled, filtered, and washed with methanol to give the colored metal complexes, and the pure product was obtained after recrystallization from methanol. All the metal complexes used in this study have been characterised using similar methods. The colour, yield, and spectral and elemental data of the complexes are given next.

MnL. Reddish purple, $3.64 \mathrm{~g}, 72 \%$ yield. FTIR [ $\mathrm{KBr}$ pellets, $v(\max ), \mathrm{cm}^{-1}$ ]: 3360, 3050,1640, 1530, 748, 620, 550, MALDI-TOF MS (m/z): $502.61\left[\mathrm{M}+\mathrm{H}^{+}\right]$, Anal. Calcd for $\mathrm{C}_{28} \mathrm{H}_{18} \mathrm{O}_{4} \mathrm{~N}_{2}-\mathrm{Mn}$ (II): C, 67.07\%; H, 3.62\%; N, 5.59\%; Mn, $10.96 \%$. Found: C, 67.08\%; H, 3.63\%; N, 5.57\%; Mn, $10.94 \%$.

CoL. Dark brown, 3.54g, 70\% yield. FTIR [KBr pellets, $\left.v(\max ), \mathrm{cm}^{-1}\right]$ : 3360, 3050,1640, 1538, 748, 620, 540, MALDI-TOF MS (m/z): 506.03, Anal. Calcd for $\mathrm{C}_{28} \mathrm{H}_{18} \mathrm{O}_{4} \mathrm{~N}_{2}-\mathrm{Mn}(\mathrm{II}): \mathrm{C}, 66.54 \% ; \mathrm{H}, 3.59 ; \mathrm{N}, 5.54 \%$; Co, $11.66 \%$. Found: C, 66.54\%; H, 3.60\%; N, 5.55\%; Co, $11.68 \%$.

NiL. Purple, $3.69 \mathrm{~g}, 73 \%$ yield. FTIR $[\mathrm{KBr}$ pellets, $\left.v(\max ), \mathrm{cm}^{-1}\right]:$ 3360, 3055,1642, 1540, 745, 625, 540, MALDI-TOF MS (m/z): 505.12, Anal. Calcd for $\mathrm{C}_{28} \mathrm{H}_{18} \mathrm{O}_{4} \mathrm{~N}_{2}-\mathrm{Ni}(\mathrm{II}): \mathrm{C}, 66.57 \%$; $\mathrm{H}, 3.59 ; \mathrm{N}, 5.55 \%$; Co, 11.62\%. Found: C, 66.58\%; H, 3.61\%; N, 5.56\%; Ni, 11.63 .

CuL. Dark purple, 3.52 g, 69\% yield. FTIR [KBr pellets, $\left.v(\max ), \mathrm{cm}^{-1}\right]:$ 3360, 3050,1645, 1535, 748, 620, 545, MALDI-TOF MS (m/z): 510.6, Anal. Calcd for $\mathrm{C}_{28} \mathrm{H}_{18} \mathrm{O}_{4} \mathrm{~N}_{2-}$ $\mathrm{Cu}(\mathrm{II}): \mathrm{C}, 65.94 \%$; H, 3.56; N, 5.49\%; Cu, 12.62\%. Found: C, $65.95 \% ; \mathrm{H}, 3.57 \%$; N, 5.51\%; Co, $12.63 \%$.

ZnL. Reddish purple, $3.62 \mathrm{~g}, 71 \%$ yield. ${ }^{1} \mathrm{H}-\mathrm{NMR}$ (300 MHz, DMSO, d): 9.56 (2H, OH), 7.52-6.45 (12 hours, Ar-H), $9.16(2 \mathrm{H}, \mathrm{CH}=\mathrm{N})$, FTIR $[\mathrm{KBr}$ pellets, $v(\max )$, $\mathrm{cm}^{-1}$ ]: 3360, 3055,1645, 1540, 750, 620, 540, MALDI-TOF MS (m/z): 511.42, Anal. Calcd for $\mathrm{C}_{28} \mathrm{H}_{18} \mathrm{O}_{4} \mathrm{~N}_{2}-\mathrm{Zn}(\mathrm{II}): \mathrm{C}$, 66.54\%; H, 3.59; N, 5.54\%; Co, 11.66\%. Found: C, 66.54\%; $\mathrm{H}, 3.60 \%$; N, 5.55\%; Co, $11.68 \%$.

2.5. Synthesis of Metal-Containing Epoxy Polymers. The epoxidation of metal complexes was carried out by the reaction of Schiff base metal complexes (ML) with epichlorohydrin [14]. A mixture of (0.01 mol) ML dissolved in $20 \mathrm{~mL}$ DMF and $10 \mathrm{~mL}$ of epichlorohydrin was refluxedin a threeround-bottom flask in the presence of sodium hydroxide $(10 \mathrm{~mL}$ of $2 \mathrm{~N}$ ) was added gradually for $4 \mathrm{~h}$. The progress of the reaction was monitored by TLC technique, and epoxide value as the heat evolution was slowed; the solution was poured in to ice cooled ether. The resulting colour precipitate of metal-containing epoxy polymers was filtered, washed with water and methanol, respectively, and dried in vacuum oven at $100^{\circ} \mathrm{C}$ for $2 \mathrm{~h}$.

2.6. Antibacterial Assessments. The antibacterial activities of the chelated epoxy polymers were performed according to the National Committee for Clinical Laboratory Standards (NCCLS) to determine minimum inhibitory concentration (MIC) values [15]. The microorganisms used in this study were $S$. aureus, B. subtilis (Gram-positive bacteria) and E. coli,P. aeruginosa (Gram-negative bacteria). The strains 


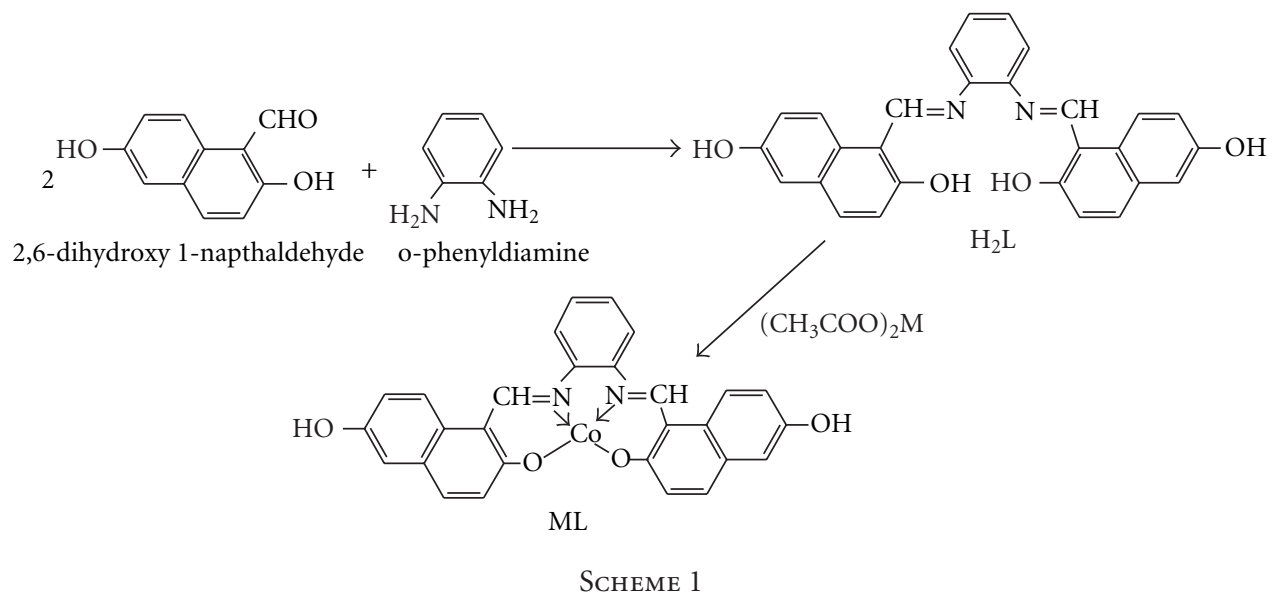

were all cultured on Tryptic Soy Agar (TSA) (Difco, USA) and Mueller-Hinton Broth (MHB) (Difco, USA), incubated aerobically at $35.5^{\circ} \mathrm{C}$ overnight. For the growth culture, one colony from culture on the TSA was inoculated into the $\mathrm{MHB}$ and incubated aerobically at $35.5^{\circ} \mathrm{C}$ for 24 hours. Then bacterial concentrations were determined by measuring optical density (OD) at $\lambda=600 \mathrm{~nm}$ at 0.2 (OD of 0.2 corresponded to a concentration of $10^{8} \mathrm{CFU} / \mathrm{mL}$ ) with a spectrophotometer.

The $\mathrm{MIC}_{90 \%}$ of the-metal-containing epoxy polymers was determined by modification of the broth dilution method in 96-well microtiter plate. The growth of bacteria was determined at the difference in absorbance after 24 hours incubation at $35.5^{\circ} \mathrm{C}$. The absorbance at $600 \mathrm{~nm}$ was then determined by using microplate reader. All experiments were performed in triplicates against each tested microorganisms. The lowest concentration which inhibited microbial growth was reported as $\mathrm{MIC}_{90 \%}$ whereas minimal bactericidal concentration $(\mathrm{MBC})$ was defined as the lowest concentration of the compound to kill the microorganisms [16].

\section{Result and Discussion}

3.1. Synthesis of Metal Complexes. It has been known that Schiff base ligand was synthesized by the reaction of carbonyl compound and primary amine. In this study, we have synthesized $\mathrm{H}_{2} \mathrm{~L}$ from 2,4 dihydroxy 1-napthaldehyde and o-phenylenediamine. The metal complexes were prepared by adding the methanolic solution of metal acetate to the THF solution of $\mathrm{H}_{2} \mathrm{~L}$ in $1: 1$ molar ratio as given in Scheme 1. The synthesized metal complexes were soluble in DMSO, THF, and DMF but insoluble in methanol, ethanol, acetone, and water. The formation of $\mathrm{H}_{2} \mathrm{~L}$ and its metal complexes was supported by elemental analysis, FTIR and ${ }^{1} \mathrm{HNMR}$ spectroscopy. The FTIR spectrum of $\mathrm{H}_{2} \mathrm{~L}$ showed a strong peak at $1641 \mathrm{~cm}^{-1}$, which was assigned to the $\mathrm{C}=\mathrm{N}$ stretching in the case of metal complexes this peak was shifted to lower frequency at $1605-1610 \mathrm{~cm}^{-1}$, due to metal ions coordination through imines nitrogen. Two addition peaks at $620-662 \mathrm{~cm}^{-1}$ and $540-550 \mathrm{~cm}^{-1}$ were found in the spectra of metal complexes corresponding to $\mathrm{M}-\mathrm{O}$ and $\mathrm{M}-\mathrm{N}$ bond, respectively, [17].
The ${ }^{1} \mathrm{HNMR}$ spectrum of $\mathrm{H}_{2} \mathrm{~L}$ showed a resonance signal at $9.84 \mathrm{ppm}$ for $\mathrm{HC}=\mathrm{N}$ group, which had actually shifted downfield from its position in the spectrum of metal complexes and showed resonance at $9.16 \mathrm{ppm}$. The overall profiles of metal complexes are similar and supported by elemental analysis.

3.2. Synthesis of Metal-Containing Epoxy Polymers. Epoxy resins are prepared by the step-polymerization of a bisphenol, and epichlorohydrin [18]. Herein, E-M(II) was prepared by the reaction of Schiff base metal complexes (LM) with epichlorohydrin in the presence of a sodium hydroxide according to Scheme 2. The reaction mechanism is similar to that we describe in our previous work [14]. All of the synthesized metal-containing epoxy polymers were colored solids insoluble in water, ethanol, and methanol but soluble in DMF and DMSO. E-M(II) was prepared in a molar ratio of 2 : 1 epichlorohydrin to Schiff base metal complexes, which was supported by the physicochemical properties (Epoxy value, hydroxyl value, and Chlorine value) and elemental analysis, as listed in Table 1 . The epoxy value of all the polymers was found in the range $0.18-0.22 \mathrm{~mol} / 100 \mathrm{~g}$. Medium molecular weights in the range 2225-2300 were found by the reduction of the amount of excess epichlorohydrin. The chlorine content of all the epoxy polymers was found to be $0.01-0.012 \mathrm{~mol} / 100 \mathrm{~g}$ due to many side reactions such as dehydrohalogenation [19]. The secondary hydroxyl group content (hydroxyl value) was found in the range of $0.24-$ $0.28 \mathrm{~mol} / 100 \mathrm{~g}$, which was formed along the chain molecule after the epoxy group was reduced.

The spectra of all the chelated epoxy resin showed a broad band in the range $3345-3410 \mathrm{~cm}^{-1}$, assigned to $v(\mathrm{OH})$, which suggested the presence of hydroxyl groups. The presence of methylene groups in all the polymers was confirmed by the appearance of two strong bands at 2940 and $2860 \mathrm{~cm}^{-1}$ due to $v \mathrm{C}-\mathrm{H}$ symmetric and asymmetric stretching and a band at $1415 \mathrm{~cm}^{-1}$ due to the $\delta \mathrm{CH}_{2}$ bending mode. All of the synthesized compounds showed additional absorption bands around 1260,1165, and $890 \mathrm{~cm}^{-1}$ associated with epoxy groups although a band at $1260 \mathrm{~cm}^{-1}$ was identified with some reasonable certainty as being due to epoxy groups 


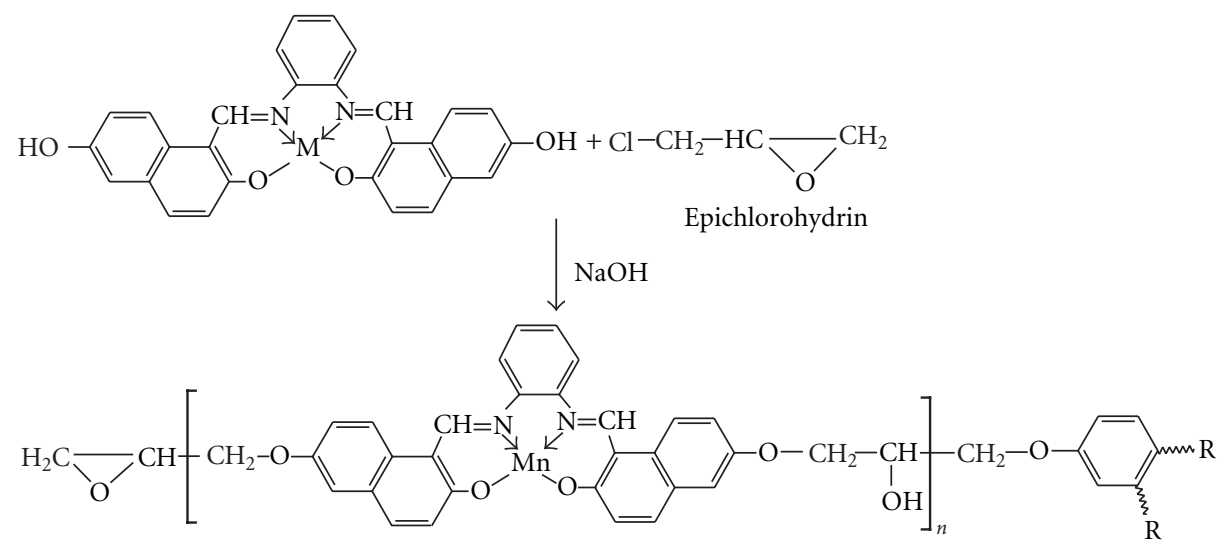

Scheme 2

TABLe 1: Physicochemical properties and elemental analysis of metal-cheated epoxy polymers.

\begin{tabular}{|c|c|c|c|c|c|c|c|c|}
\hline \multirow{2}{*}{ Abbreviation } & \multirow{2}{*}{ Yield (\%) } & \multirow{2}{*}{$\begin{array}{l}\text { Epoxy Value } \\
\text { mol/100 g }\end{array}$} & \multirow{2}{*}{$\begin{array}{l}\text { Hydroxyl value } \\
\mathrm{mol} / 100 \mathrm{~g}\end{array}$} & \multirow{2}{*}{$\begin{array}{l}\text { Chlorine value } \\
\mathrm{mol} / 100 \mathrm{~g}\end{array}$} & \multicolumn{4}{|c|}{ Elemental Analysis (\%) ${ }^{\mathrm{a}}$} \\
\hline & & & & & Carbon & Hydrogen & Nitrogen & metal \\
\hline E-Mn(II) & 70 & 0.22 & 0.24 & 0.010 & $\begin{array}{l}66.56 \\
(66.54)\end{array}$ & $\begin{array}{l}4.27 \\
(4.26)\end{array}$ & $\begin{array}{l}4.57 \\
(4.58)\end{array}$ & $\begin{array}{l}8.95 \\
(8.97)\end{array}$ \\
\hline $\mathrm{E}-\mathrm{Co}(\mathrm{II})$ & 68 & 0.18 & 0.27 & 0.012 & $\begin{array}{l}66.13 \\
(66.14)\end{array}$ & $\begin{array}{l}4.24 \\
(4.26)\end{array}$ & $\begin{array}{l}4.54 \\
(4.58)\end{array}$ & $\begin{array}{l}9.54 \\
(8.57)\end{array}$ \\
\hline E-Ni(II) & 73 & 0.19 & 0.26 & 0.010 & $\begin{array}{l}66.16 \\
(66.15)\end{array}$ & $\begin{array}{l}4.25 \\
(4.26)\end{array}$ & $\begin{array}{l}4.54 \\
(4.52)\end{array}$ & $\begin{array}{l}9.51 \\
(9.52)\end{array}$ \\
\hline $\mathrm{E}-\mathrm{Cu}(\mathrm{II})$ & 72 & 0.20 & 0.28 & 0.011 & $\begin{array}{l}65.64 \\
(65.64)\end{array}$ & $\begin{array}{l}4.21 \\
(4.22)\end{array}$ & $\begin{array}{l}4.50 \\
(4.51)\end{array}$ & $\begin{array}{l}10.21 \\
(10.20)\end{array}$ \\
\hline $\mathrm{E}-\mathrm{Zn}(\mathrm{II})$ & 74 & 0.21 & 0.28 & 0.012 & $\begin{array}{l}65.44 \\
(65.43)\end{array}$ & $\begin{array}{l}4.20 \\
(4.20)\end{array}$ & $\begin{array}{l}4.49 \\
(4.48)\end{array}$ & $\begin{array}{l}10.48 \\
(10.47)\end{array}$ \\
\hline
\end{tabular}

${ }^{\mathrm{a}}$ The values are presented as calculated (found).

and a second band at $1155-1070 \mathrm{~cm}^{-1}$ was probably due to $\mathrm{CH}_{2}-\mathrm{O}$ vibrations when comparing their parental Schiff base ligand [20].

The ${ }^{1} \mathrm{H}-\mathrm{NMR}$ and ${ }^{13} \mathrm{C}-\mathrm{NMR}$ spectra of the diamagnetic metal-chelated epoxy resin were determined in DMSO- $\mathrm{d}_{6}$ and are given in Figures 1 and 2 . The ${ }^{1} \mathrm{H}-\mathrm{NMR}$ spectra of these resins showed strong singlet signals at $9.20 \mathrm{ppm}$, which suggested azomethine protons $(\mathrm{CH}=\mathrm{N})$. The alcoholic protons $(\mathrm{OH})$ showed a single resonance signal at $4.50 \mathrm{ppm}$ in the case of $\mathrm{E}-\mathrm{Zn}$ (II); this resonance signal was not found for ML. The chelated resin showed some other signals, assigned labels in Figure 1, at 2.20-3.02 ppm due to methylene protons in different environments. The number of protons calculated from the integration curves and those obtained from the values of the expected $\mathrm{CHN}$ analyses were in agreement. In the ${ }^{13} \mathrm{C}$-NMR spectra, $\mathrm{Zn}$-chelated epoxy resin displayed signals assigned to $\mathrm{CH}=\mathrm{N}$ carbons at $155 \mathrm{ppm}$. This signal appeared downfield in comparison with their original position $(168 \mathrm{ppm})$, which indicated coordination with the central metal atom. A sharp peak at $62.2 \mathrm{ppm}$, assigned to the $\mathrm{CH}-\mathrm{OH}$ function, was generated due to the reduction of oxirane groups with reactive hydrogen. Other resonance lines of these spectra fell into two main regions at 66.5-68.6 ppm for aliphatic carbons and 125-150.08 ppm for aromatic carbons [21].

A comparative study of the thermal behaviours of all the epoxy polymers was carried out in a nitrogen atmosphere with the purpose of examining the structure-property relationships at various temperatures, and results are given in Table 2. All of the polymers decomposed in two steps; the first step was faster than the second step as given in Figure 3. This may have been due to the fact that the noncoordinated part of the polymers decomposed first, and the actually coordinated part of the polymers decomposed later. The TGA trace of E-Cu(II) showed the initial decomposition at $450^{\circ} \mathrm{C}$, about $10 \%$ weight loss was observed, which corresponded to an aliphatic portion/noncoordinated part such as $\mathrm{CH}_{2}-\mathrm{CH}-\mathrm{CH}_{2}$ and epoxy groups per units of epoxy resin. Then, continued mass loss was observed up to $575^{\circ} \mathrm{C}$, which indicated the decomposition and volatilization of the aromatic part into low-molecular-weight fractions, such as $\mathrm{CH}_{4}, \mathrm{~N}_{2}$ and $\mathrm{H}_{2} \mathrm{O}$. The thermogravimetric analysis (TG) of the chelated epoxy polymers revealed a mass loss in the temperature range $550-580^{\circ} \mathrm{C}$, which corresponded to 
TABLE 2: Thermal behaviors of metal-chelated epoxy polymers.

\begin{tabular}{|c|c|c|c|c|c|c|c|}
\hline \multirow{2}{*}{ Abbreviation } & \multirow{2}{*}{$\mathrm{T}_{\mathrm{g}}\left({ }^{\circ} \mathrm{C}\right)$} & \multicolumn{5}{|c|}{ Temperature $\left({ }^{\circ} \mathrm{C}\right)$ corresponding to a weight loss } & \multirow{2}{*}{$\begin{array}{l}\text { Char. (\%) } \\
\text { weight at } \\
800^{\circ} \mathrm{C}\end{array}$} \\
\hline & & $10 \%$ & $20 \%$ & $30 \%$ & $40 \%$ & $50 \%$ & \\
\hline E-Mn(II) & 226 & 242 & 377 & 420 & 473 & 543 & 22.50 \\
\hline E-Co(II) & 228 & 240 & 360 & 400 & 467 & 538 & 25.21 \\
\hline $\mathrm{E}-\mathrm{Ni}(\mathrm{II})$ & 231 & 277 & 400 & 460 & 537 & 596 & 28.50 \\
\hline E-Cu(II) & 236 & 275 & 428 & 458 & 514 & 562 & 34.20 \\
\hline E-Zn(II) & 234 & 360 & 382 & 422 & 498 & 544 & 32.05 \\
\hline
\end{tabular}

$\mathrm{Tg}\left({ }^{\circ} \mathrm{C}\right)$-glass transition temperature.

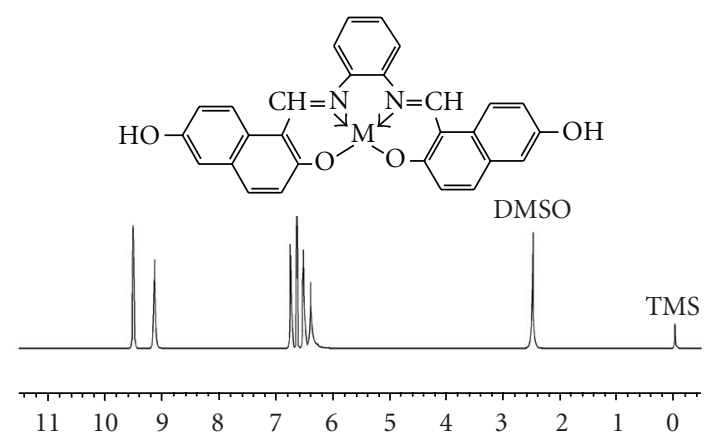

(a)

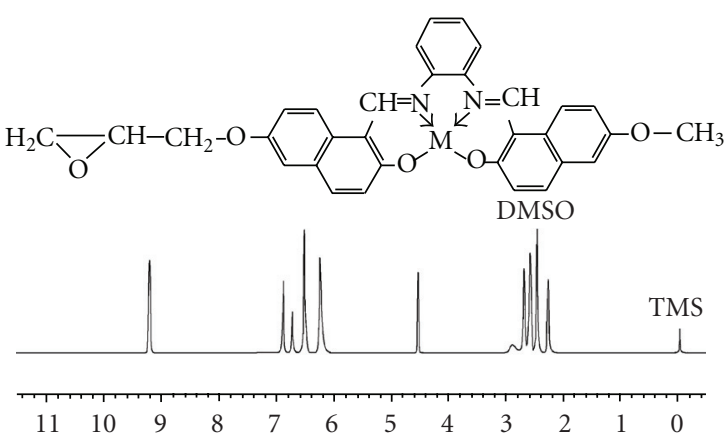

(b)

Figure 1: ${ }^{1} \mathrm{H}-\mathrm{NMR}$ spectra of (a) (ZnL) Schiff base complexes and (b) Zn chelated epoxy polymers.

the formation of metal diisocyanate $\left[\mathrm{M}(\mathrm{OCN})_{2}\right]$. The next decomposition step occurred in the temperature range 610 $800^{\circ} \mathrm{C}$ and corresponded to the thermal decomposition of $\mathrm{M}(\mathrm{OCN})_{2}$ to metal isocyanate $[\mathrm{M}(\mathrm{OCN})]$ and corresponded to the formation of MO [22]. The reduced masses of $34.20 \%, 32.05 \%, 28.50 \%, 25.21 \%$, and $22.50 \%$ were found at $800^{\circ} \mathrm{C}$, corresponded to E-Cu(II), E-Zn(II), E-Ni(II), E$\mathrm{Co}(\mathrm{II})$ and $\mathrm{E}-\mathrm{Mn}(\mathrm{II})$, respectively, and matched with IrvinWilliams order of stability of complexes of divalent metal ions. The observed reduced masses of all of the epoxy resin were greater than the calculated values; this was due to the formation of other compounds during the thermal reaction. Differential scanning calorimetry results of these epoxy resins revealed that the heat flow rate of the samples

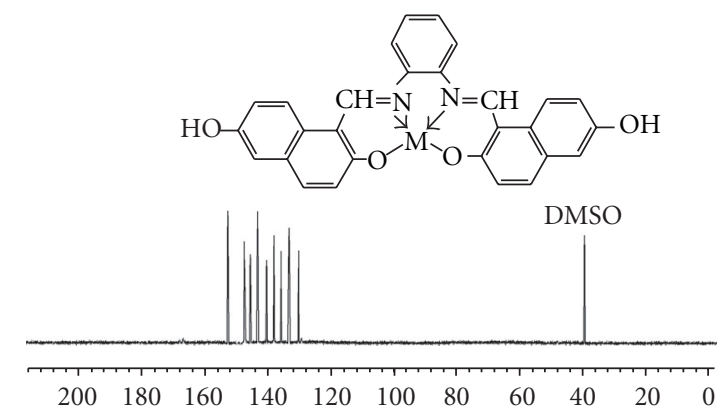

(a)

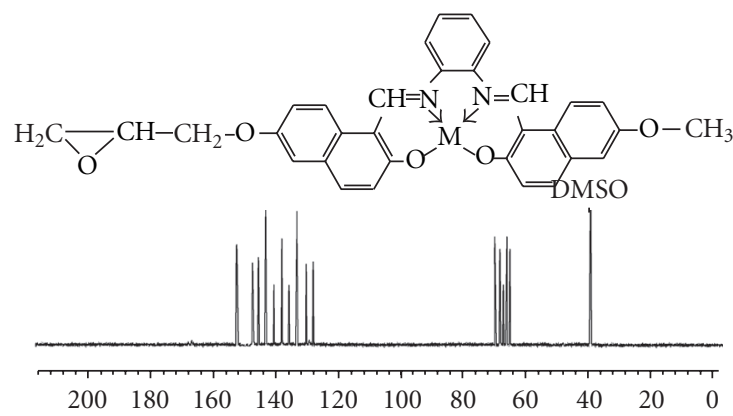

(b)

Figure 2: ${ }^{13} \mathrm{C}$-NMR spectra of (a) (ZnL) Schiff base complexes and (b) Zn chelated epoxy polymers.

underwent a change during transition. The Tg values of all of the synthesized epoxy resins were computed from the results by the extrapolation of the pretransition and post transition line and by the calculation of the temperature when the heat flow rate was exactly in the middle of the pretransition and post transition rates. The $\mathrm{Tg}$ values of all of the synthesized polymers were in the range $180-220^{\circ} \mathrm{C}$ and are given in Table 2 . All of the polymers showed a single Tg value due to the absence of any homopolymers, block polymers, and heterogeneous impurities [23].

3.3. Antibacterial Activity. The in vitro antibacterial activity of all the synthesized polymers was evaluated by using a minimum inhibitory concentration (MIC) and a minimum 
TABLe 3: Antibacterial activity of metal-chelated epoxy polymers.

\begin{tabular}{lcccc}
\hline \multirow{2}{*}{ Abbreviation } & & \multicolumn{2}{c}{ MIC/MBC $(\mu \mathrm{g} / \mathrm{ML})^{\mathrm{a}}$} & \\
& E. coli & P. aeruginosa & S. aureus & $760 / 840$ \\
E-Mn(II) & $800 / 850$ & $790 / 825$ & $750 / 830$ & $740 / 840$ \\
E-Co(II) & $800 / 840$ & $750 / 840$ & $740 / 820$ & $740 / 820$ \\
E-Ni(II) & $790 / 820$ & $740 / 840$ & $720 / 800$ & $720 / 810$ \\
E-Cu(II) & $730 / 800$ & $730 / 810$ & $730 / 830$ & $730 / 820$ \\
E-Zn(II) & $740 / 820$ & $740 / 820$ & \\
\hline
\end{tabular}

${ }^{\mathrm{a}} \mathrm{MIC} / \mathrm{MBC}( \pm 4)$, experiment were repeated three times.

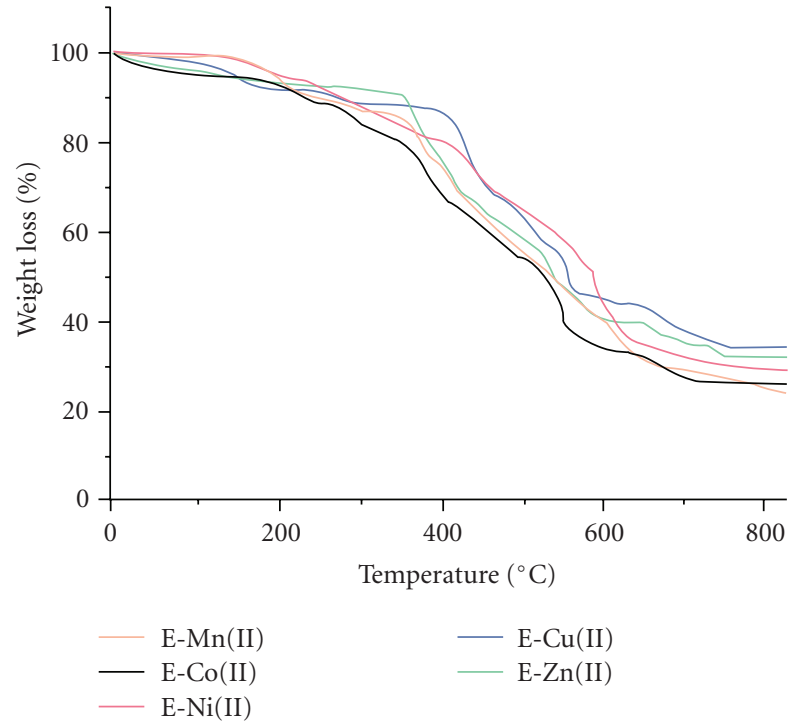

FIgURE 3: Thermogram of metal-chelated epoxy polymers.

bactericidal concentration (MBC) procedure against $S$. aureus, B. subtilis (Gram-positive bacteria), and E. coli, $P$. aeruginosa (Gram-negative bacteria) bacteria accordance to methods of the National Committee for Clinical Laboratory Standards (NCCLSs) $[15,16]$. The metal-chelated epoxy polymers inhibited growth of all the bacteria with MIC values ranging between 720 and $800 \mu \mathrm{g} / \mathrm{mL}$ whereas MBC value was $850 \mu \mathrm{g} / \mathrm{mL}$ displayed in Table 3. It was revealed that $E$. coli and $P$. aeruginosa were more sensitive to the chelated epoxy polymer than that of the other two bacteria due to the different component of bacterial cell wall. It was also observed that the E-Cu(II) showed higher MIC/MBC value $730 / 800,740 / 810,720 / 800$ and $720 / 810$ against $S$. aureus, B. subtilis, E. coli, and $P$. aeruginosa bacteria. On the other hand, the E-Mn(II) displayed lower antibacterial activity than that of other chelated epoxy polymers. In our previous study, we reported that chelation or coordination reduces the polarity of the metal ion by partial sharing of its positive charge with the donor groups and possibly pelectron delocalization within the whole chelate ring. This process thus increases the lipophilic nature of the compound, which, in turn, favors penetration through the bacterial wall of the microorganism. The $\mathrm{Cu}(\mathrm{II})$-chelated resin showed the widest effective antibacterial due to a higher stability constant [24]. On the other hand, the difference in the magnitude of antimicrobial activity came from other factors, such as solubility, charge, and chirality of the polymers. Thus, it was apparent that the antibacterial activity of the chelated polymers of Schiff base was not only dependent on the charge but also on the chemical structure and nature of metal ions.

\section{Conclusion}

Metal-chelated epoxy polymers were successfully synthesized by the polycondensations of Schiff base metal complexes with epichlorohydrin in the basic medium and characterized by elemental, spectral, and thermal analysis. All the epoxy polymers in this study were colored solid, insoluble in common organic solvent but soluble in DMSO and DMF. The signal Tg value represents absence of any homopolymers, block polymers, and heterogeneous impurities. E-Cu(II) shows good thermal resistant as well as microbial resistant behaviour due to higher stability constant. Due to the promising thermal and microbial resistant behaviours, these polymers could be used as heat resistant-coating materials for aero space vehicles and antimicrobial coating materials in public palace and hospitals.

\section{Acknowledgment}

The authors are gratefully acknowledged to "Center of Excellence for Research In Engineering Materials" King Saud University, Kingdom of Saudi Arabia for financial support to complete this work, Project (430-CEREM-05).

\section{References}

[1] D. Sridaeng and N. Chantarasiri, "Thermally stable polyureas and poly(urea-imide)s containing zinc and nickel napthtrien complexes," Journal of Applied Polymer Science, vol. 114, no. 6, pp. 3945-3954, 2009.

[2] J.-Y. Cheng, Y.-B. Dong, R.-Q. Huang, and M. D. Smith, "Synthesis and characterization of new coordination polymers generated from oxadiazole-containing ligands and IIB metal ions," Inorganica Chimica Acta, vol. 358, no. 4, pp. 891-902, 2005.

[3] I. D. Kosobudskii, L. V. Kashkina, S. P. Gubin, G. A. Petrakovskii, V. P. Piskorskii, and N. M. Svirskaya, "New type of metal-containing polymers- metallic clusters in polymer matrices," Polymer Science U.S.S.R., vol. 27, no. 4, pp. 768-775, 1985. 
[4] N. Chantarasiri, T. Damrongkosit, W. Jangwong, D. Sridaeng, and S. Suebphan, "Synthesis, characterization and thermal properties of metal-containing polyurethane-ureas from hexadentate Schiff base metal complexes," European Polymer Journal, vol. 40, no. 8, pp. 1867-1874, 2004.

[5] N. Chantarasiri, T. Tuntulani, P. Tongraung, R. Seangprasertkit-Magee, and W. Wannarong, "New metal-containing epoxy polymers from diglycidyl ether of bisphenol A and tetradentate Schiff base metal complexes," European Polymer Journal, vol. 36, no. 4, pp. 695-702, 2000.

[6] F. B. Paul, Epoxy Resin Technology, Interscience, New York, NY, USA, 1968.

[7] N. Chantarasiri, N. Sutivisedsak, and C. Pouyuan, "Thermally stable metal-containing epoxy polymers from an epoxy resinSchiff base metal complex-maleic anhydride system," European Polymer Journal, vol. 37, no. 10, pp. 2031-2038, 2001.

[8] A. V. Kurnoskin, "Heat resistance of metal-containing epoxy chelate polymers," Polymer Degradation and Stability, vol. 37, no. 1 , pp. 51-59, 1992.

[9] M. Cazacu, M. Marcu, A. Vlad, G. I. Rusu, and M. Avadanei, "Chelate polymers. VI. New copolymers of the some siloxane containing bis(2,4-dihydroxybenzaldehydimine) $\mathrm{Me}^{2+}$ with bis( $p$-carboxyphenyl)diphenylsilane," Journal of Organometallic Chemistry, vol. 689, no. 19, pp. 3005$3011,2004$.

[10] H. Matsuda, "Polymers based on divalent metal salts of paminobenzoic acid: a review," Polymers for Advanced Technologies, vol. 8, no. 10, pp. 616-622, 1997.

[11] H. Houjou, T. Motoyama, and K. Araki, "Electronic spectra of mono- and dinuclear complexes of fully $\pi$-conjugated salphen ligands synthesized by using 2,6-dihydroxynaphthalene carbaldehydes," European Journal of Inorganic Chemistry, no. 4, pp. 533-538, 2009.

[12] O. Ekberov and S. Basan, Polymer Chemistry Lab, Cumhuriyet University Press, Sivas, Turkey, 1995.

[13] H. Lee and K. Neville, Handbook of Epoxy Resine, McGrawHill, New York, NY, USA, 1972.

[14] N. Nishat, S. Ahmad, and T. Ahamad, "Synthesis, characterization, and antimicrobial studies of newly developed metalchelated epoxy resins," Journal of Applied Polymer Science, vol. 101, no. 3, pp. 1347-1355, 2006.

[15] National Committee for Clinical Laboratory Standards, Methods for Dilution Antimicrobial Susceptibility Tests for Bacteria that Grow Aerobically. Approved Standard, National Committee for Clinical Laboratory Standards, Wayne, Pa, USA, 5th edition, 2000, M7A5.

[16] National Committee for Clinical Laboratory Standards, Performance Standards for Antimicrobial Susceptibility Testing. 8th Informational Supplement, National Committee for Clinical Laboratory Standards, Villanova, Pa, USA, 2002, M100 S12.

[17] T. Ahamad, N. Nishat, and S. Parveen, "Synthesis, characterization and anti-microbial studies of a newly developed polymeric Schiff base and its metal-polychelates," Journal of Coordination Chemistry, vol. 61, no. 12, pp. 1963-1972, 2008.

[18] T. Ahamad and N. Nishat, "New antimicrobial epoxy-resinbearing schiff-base metal complexes," Journal of Applied Polymer Science, vol. 107, no. 4, pp. 2280-2288, 2008.

[19] E. Sahmetlioglu, H. Mart, H. Yuruk, and Y. Surme, "Synthesis and characterization of oligosalicylaldehyde-based epoxy resins," Chemical Papers, vol. 60, no. 1, pp. 65-68, 2006.

[20] N. B. Colthup, L. J. Daly, and S. E. Wiberly, Introduction to Infrared and Raman Spectroscopy, Academic, New York, NY, USA, 2nd edition, 1975.
[21] N. Nishat, S. Parveen, S. Dhyani, Asma, and T. Ahamad, "Synthesis, characterization, and thermal and antimicrobial studies of newly developed transition metal-polychelates derived from polymeric Schiff base," Journal of Applied Polymer Science, vol. 113, no. 3, pp. 1671-1679, 2009.

[22] T. Ahamad, V. Kumar, and N. Nishat, "New class of anti-microbial agents: synthesis, characterization, and antimicrobial activities of metal chelated polyurea," Journal of Biomedical Materials Research A, vol. 88, no. 2, pp. 288-294, 2009.

[23] M. Anand and A. K. Srivastava, "Synthesis and characterization of epoxy resins containing transition metals," Polymer, vol. 34, no. 13, pp. 2860-2864, 1993.

[24] V. Kumar, T. Ahamad, and N. Nishat, "Some $O, O^{\prime}, O^{\prime \prime}, O^{\prime \prime \prime}$ di/tetra aryldithioimidophonate transition metal complexes derived from catechol and bisphenol-A as antibacterial and antifungal agents," European Journal of Medicinal Chemistry, vol. 44, no. 2, pp. 785-793, 2009. 


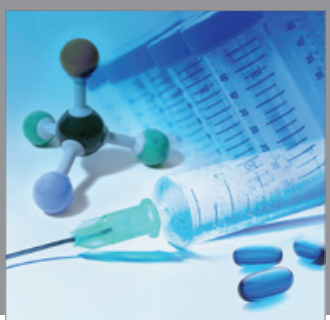

International Journal of

Medicinal Chemistry

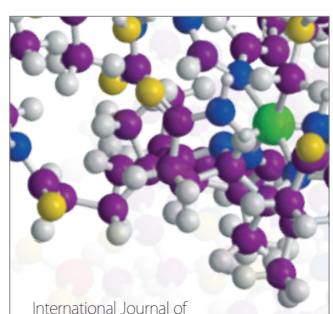

Carbohydrate Chemistry

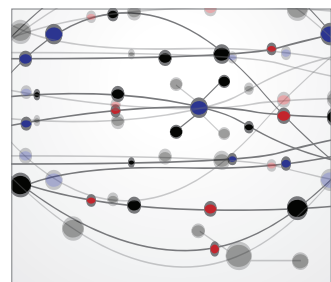

The Scientific World Journal
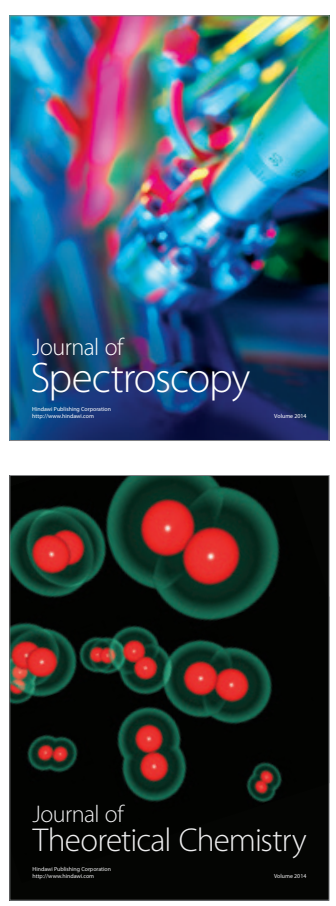
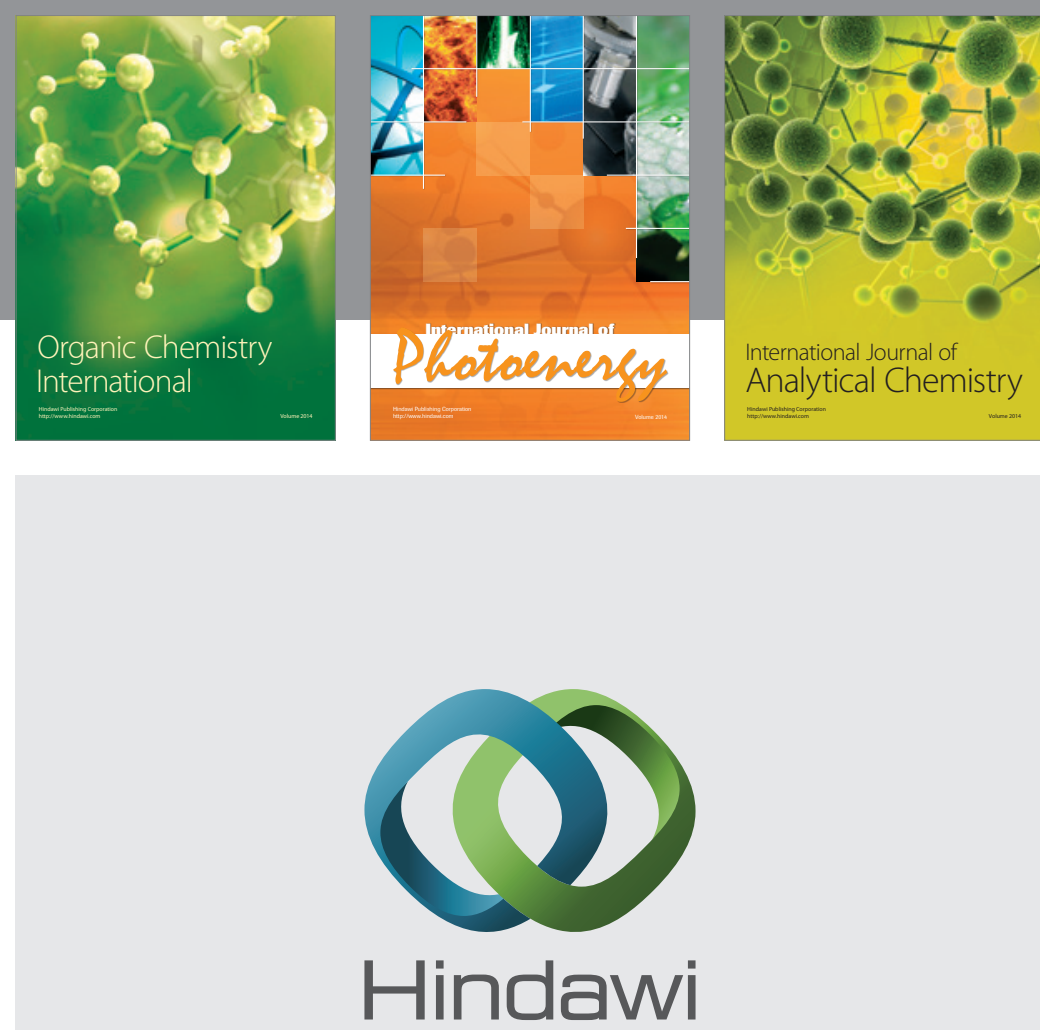

Submit your manuscripts at

http://www.hindawi.com
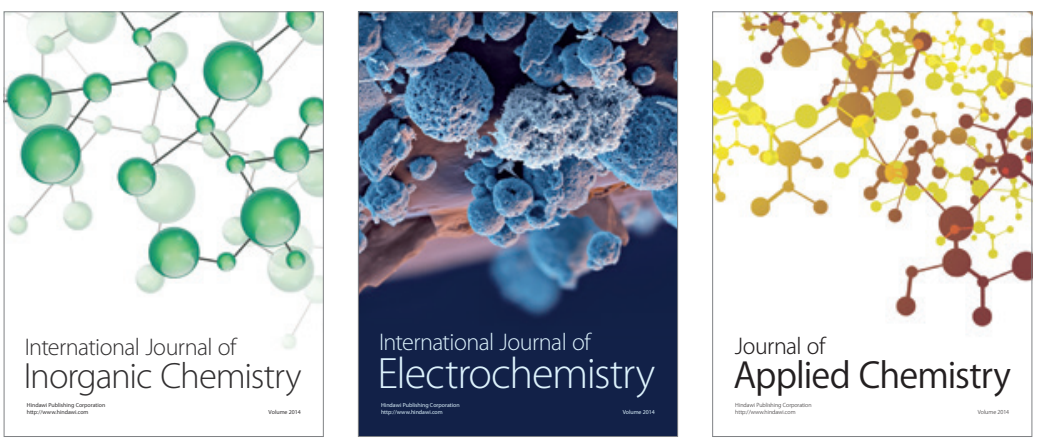

Journal of

Applied Chemistry
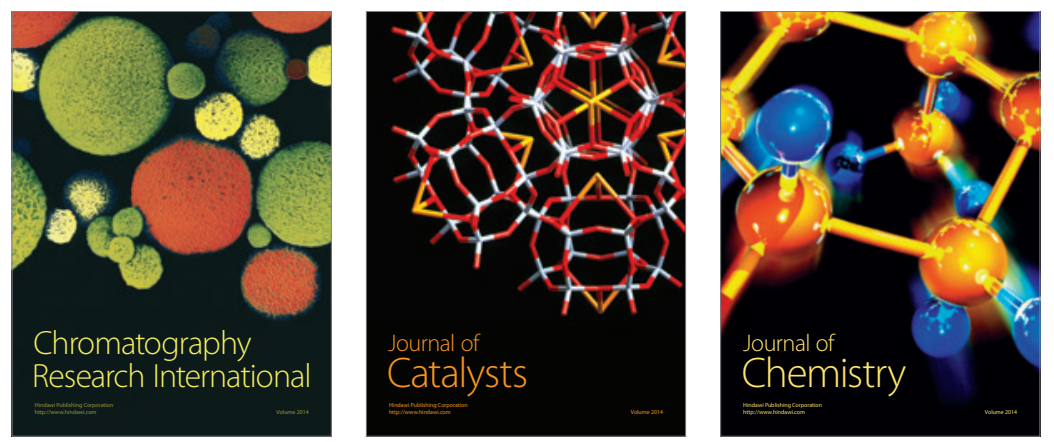
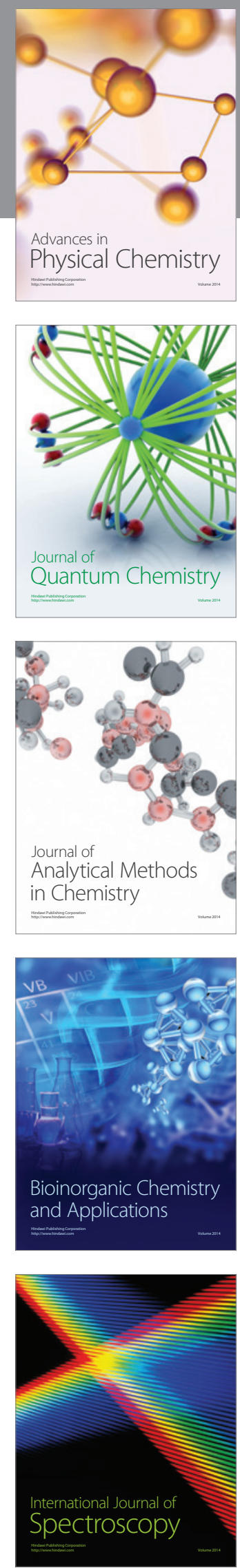